\title{
The Static Fluid Animation (Macromedia Flash) to Improving Student's Physics Learning Outcomes
}

\author{
Marnita $^{1}$, M. Taufiq ${ }^{1}$ and Mursalin ${ }^{2}$ \\ \{marnita.fkip@gmail.com \} \\ ${ }^{1}$ Department of Physics Education, Almuslim University, Bireuen, Indonesia \\ ${ }^{2}$ Department of Mathematics Education, Universitas Malikussaleh, Aceh Utara, Indonesia
}

\begin{abstract}
The lower learning outcomes of students and the activities of teachers and students is a fundamental problem in Peusangan State Madrasah Aliyah (MAN). This study aims to determine: 1) improvement of student learning outcomes; 2) teacher and student activity; and 3) student responses through the application of static fluid animation media (Macromedia Flash) on the concept of static fluid at Peusangan State Madrasah Aliyahs (MAN). This study uses a qualitative approach to the type of classroom action research.The subjects of this study are all students of class X IPA ${ }^{1}$ Peusangan State Islamic school that is 25 students in the even semester of the academic year 2016/2017. Data collection is done by tests, observations, and questionnaires. Data analysis techniques using percentages.The results showed that: 1) the improvement of students' learning outcomes by applying the media of static fluid animation (Macromedia Flash) in each cycle.2) The activity of teachers and students of class X Peusangan State Islamic schoolon the concept of static fluid has shown very good category and has increased, ie cycle I was $78.33 \%$ and cycle II increased to $95 \%$; 3) response result indicated that most of student were very happy with application of media of static fluid animation (Macromedia Flash) that is $78,8 \%$.
\end{abstract}

Keywords: StaticFluid Animation, Macromedia Flash, Learning Outcomes,

\section{Introduction}

The education cannot be separated from the role of teachers, professional teachers are expected to present education with creative so that the impact on the birth of various highthinking ability of learners. Ability to present the material of a lesson well will be able to provide encouragement and motivation to learn to students to continue to learn by utilizing facilities and infrastructure owned by the school. So it is with the subject of physics as one of the subjects that collaborate between conceptual and practical knowledge. Low of teacher ability to present the concept of physics well, causing students less enthusiastic and passive in learning. Development of science or physics learning in principle provides a great challenge for teachers in teaching. The most important challenge must be able to face by science teachers or physics teachers are teachers should be able to place itself as a motivator for students, students are able to invite to engage directly in science practice, students must also 
be able to invite to engage in scientific investigation either in the form of ideas or ideas and techniques of inquiry as well as developing the concept in a structured way [1].

The teachers as educators and educational innovators should be able to make improvements and changes in the learning system especially related to the innovation of teaching and learning process in the classroom. The system is expected that students are much more active in interacting in the classroom either with teachers or with other students. Improvements made by a teacher can be the application of innovative learning models that exist today. The hope of each teacher can give impact which is positive for the ability and the willingness of students to learn the results of student learning in schools is increasing. A teacher should pay attention to the level of student learning outcomes and overcome the problems that cause low student learning outcomes, therefore teachers need to implement a new learning program that can attract the attention of students and motivate students to be more enthusiasm learn. Teachers should also reduce the conventional methods by utilizing the media and not too pressing students with a lot of formulas that can invite student saturation in learning.

Based on observations and interviews with physics teacher at Peusangan Islamic School revealed that one of the problems in the school is the lack of interest and motivation of students to the lessons, especially physics so that the learning outcomes are still low. Therefore, based on existing problems, this research has problem formulation that is 1) How to improve student learning outcomes by using animation fluid media static Macromedia flash, 2) how the activity of teacher and student using media of fluid animation of static (Macromedia Flash) on students Islamic school, 3). How is the student's response through the application of static fluid animation media (Macromedia Flash) on the concept of static fluid at Islamic school ? Furthermore, the purpose of this study is to determine 1) improvement of student learning outcomes; 2) teacher and student activity; and 3) student responses through the application of static fluid animation media (Macromedia Flash) on the concept of static fluid at Islamic school .

The low of student learning outcomes in the cause of teachers less able to bring students to the world of students is learning while playing. The concept of play in the intent can be an animated or interactive multimedia media which will involve the advanced cognitive ability of students to design and construct their knowledge through multimedia presented by the teacher [2]. The active role of teachers to monitor and run the learning also still must be run along with the use of multimedia learning. According Brennan [2] Teachers should be able to become facilitators and guides learners activity. Brennan's presentation provides an illustration that the role of teachers and the function of teachers in the classroom is crucial to the success of learning in the classroom.

Furthermore, researchers will apply a medium of physics learning as a solution to the low ability of physics students, which multimedia is expected to be able to motivate students to learn physics, especially on static fluid material for student learning outcomes are more increased. The use of instructional media is very supportive of a teacher in explaining the concepts of physics so that the learning process is better and more effective. The use of learning media with technology gives a very positive impact on the ability and willingness of students to follow the learning process. One of the learning media that can be tested is using Macromedia Flash which is one of computer software used to design animation [3]. Further Brennan [2], stated that students who actively involved to design interactive media, will be more enthusiastic to explore and be motivated for creative learning.

Furthermore, it is still related to the media, Sadiman et al. [6] reveal that "The characteristics of the media are viewed in terms of economics, the scope of the target that can 
be covered, and ease of control by the wearer. Media characteristics can also be seen by its ability to stimulate all senses". this knowledge of the characteristics of learning media is very important for the grouping and selection of media and can be adapted to specific learning situations. Furthermore, Wiyono, et al [12] gave his opinion related to interactive multimedia ie the use of interactive multimedia in physics learning will greatly assist students in understanding abstract concepts.

With the learning process using Macromedia Flash students not only imagine, but students can see directly the concept described by the teacher. This is certainly able to attract students 'attention in teaching and learning activities in the classroom and can improving students' motivation and learning outcomes. The consequences of technological innovation in Islamic schoolnow require schools to prioritize digital media as a learning media tool that will motivate to students for active learning [10].

Interactive multimedia (Macromedia flash) as a form of digital technology can serve as a substitute for teaching methods less attractive teachers, digital technology can also create active learning conditions for students and able to build cooperation between students with students and between teachers with students, therefore in the application of interactive multimedia as one of the teaching solutions in the classroom, the teacher must still act as the controller, director and responsible [9]. Thus the researcher intends to conduct further research on the problem.

\section{Methods}

This research was conducted at Peusangan Madrasah Aliyah School is in of Bireuen Regency. This research was conducted on the students of class X IPA 1 in the even semester of the academic year 2016/2017. Started from April 5, 2017, to April 19, 2017. Subjects in this study were students of class X IPA 1 Peusangan Islamic schoolamounting to 25 students. Factors studied in this study is the ability of student learning outcomes in the measured with items about the test results of learning, teacher activity, and students are measured by using questionnaire activity, and student responses are measured by using a questionnaire response students.

This research was conducted by the qualitative method by following the Classroom Action Research design. Therefore, this research is carried out by following the following stages: planning, implementation, action, observation, and reflection. This research takes two cycles with four actions. Sources of data obtained through questionnaires of teacher and student activities, test items as well as questionnaire responses of students. The test items that are prepared in the form of multiple choice items are given at the end of each cycle.

Further data obtained have been analyzed by using some equations, that is:

1. Calculating the improvement of student learning outcomes was analyzed by calculating the absorption for each cycle using the equation as follows:

$$
\text { Absorption }=\frac{\text { Number of Students Completed }}{\text { Number of Students }} \times 100 \%
$$

The results of calculation of absorptive power, then in use the criteria mastery in classical and invidual set by Peusangan Madrasah Aliyah School namely: individual mastery if students get the value of $\geq 75$, while the mastery of the classical if the absorption reaches $85 \%$. 
2. Calculate teacher and student activity and calculate student response analyzed by using percentage, that is:

$$
P=\frac{f}{N} x 100 \%
$$

3. Students Response

To find out student response by presenting answer from questionnaire given to student with descriptive statistic as follows:

$$
P=\frac{f}{N} x 100 \%
$$

Symbol Description:

P : Percentage calculated

f : Correct answer frequency

$\mathrm{N}$ : Number of questions

Table 1.Criteria for student response

\begin{tabular}{ccc}
\hline No. & Achievement Score Total & Category \\
\hline 1. & $86-100$ & Very good \\
2. & $70-85$ & Good \\
3. & $60-69$ & Enough \\
4. & $<60$ & Less \\
\hline
\end{tabular}

\section{Result and Discussion}

In this study, the researchers conducted four stages of classroom action research that is planning, execution, observation, and reflection. This research consists of four cycles. The research begins by doing planning activities by preparing various learning tools, namely Teaching Implementation Plan (TIP), Media animation, Student's Worksheet (SW), the test is given at the end of the cycle, questionnaire observation, and response questionnaire. Static fluid animation media with Macromedia Flash is used when teachers teaching. This animated media is designed to make it easy for students to understand the material presented. The animation media is prepared for every action from cycle I to cycle II.

\subsection{Cycle I}

Implementation of action in cycle I is implemented with two actions that are actions 1 and 2 to students of class X IPA 1 on Peusangan Islamic schoolSchool which amounts to 25 students. The material presented is static fluid. Classroom learning begins by motivating students by displaying some real-life video related to the concept of static fluid. Vidio impressions are continued with the activity watching the media animated display of hydrostatic pressure concepts that have been prepared by the researchers. Furthermore, teachers form a study group assigned to perform simple experimental activities about the concept of static fluid. Each representative of the group was asked to demonstrate through the experiment, and experimental data were made into group discussion activities. The next step the teacher asks several groups to present the results of the discussion about the concept of 
static fluid. Master rewards praise to the group that works well in the group. In closing activities, the teacher together with the students concluded the learning outcomes with the students. At the end of the teaching, the teacher shared the final test of the cycle I to students to see student learning outcomes as a whole.

Teaching that took place in the classroom was observed by two observers who observed teacher activity in the implementation of student actions and activities in the teaching and learning process of students of class $\mathrm{X} \mathrm{IPA}_{1}$ static fluid material. Observation results conveyed by the next observer by the teacher with the team of observers to discuss and reflect on learning activities that have been going on. Student's learning outcomes at the end of the cycle are obtained by providing a written test item. The test item is set up with multiple choice of 10 questions. The result of the final test of the cycle I can be seen in Figure 1 below:

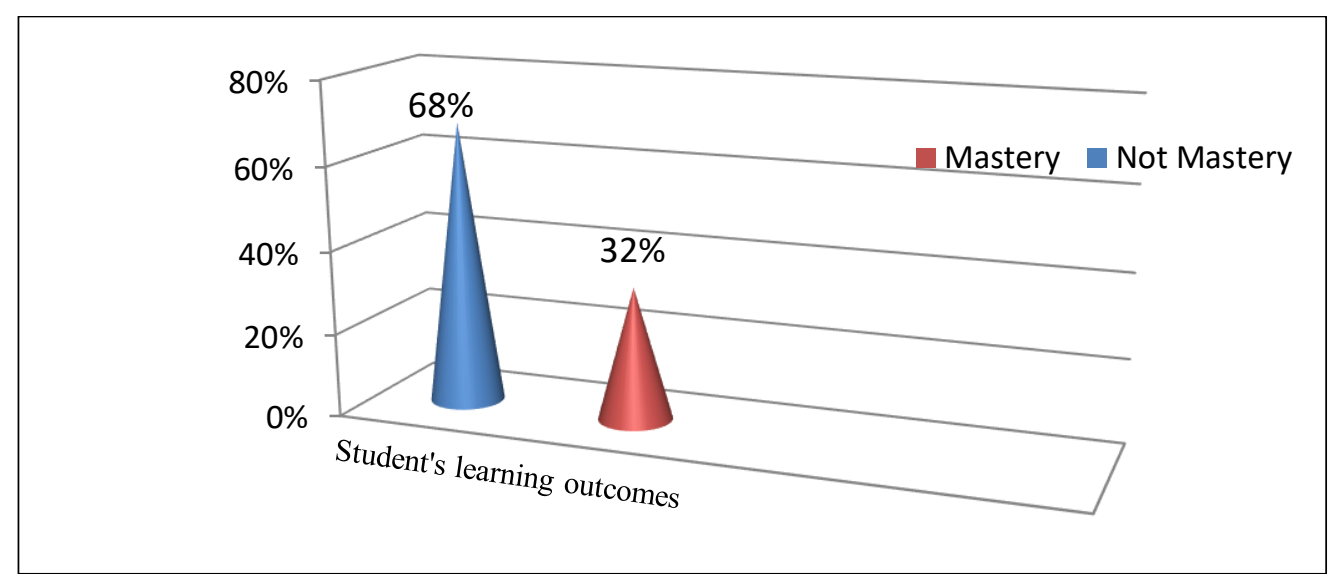

Figure 1. Results of Student Test of Cycle I

Based on the Figure 1 above can be seen that the number of students who have meet the criteria of student's learning outcomes in the school is only 17 students or equal to $68 \%$ of the total number of students treated by using static fluid animation media with Macromedia Flash. While the number of students who have not meet the criteria of student's learning outcomes is as many as 8 students or $32 \%$. Thus, the result of student learning outcomes in the first cycle has not met the criteria of student's learning outcomes individually and in classical. Observations made by two observers indicate that in the implementation of teaching and learning process

in the class I cycle, teachers and students still have some weaknesses so that the achievement of learning outcomes is not maximal or has not fulfilled the minimum mastery criteria either individually or classically. As for some weaknesses in the implementation of cycle I, namely:

a). At the introduction stage, only $40 \%$ of students are motivated to be actively involved in learning and answering some teacher questions.

b). In the demonstration and discussion activities students are less involved to conduct demonstration activities and discussion between groups, students seem busy with their own activities so that the concepts being studied are not able to be mastered by students well. 
c). Teachers are still less than optimal when directing and guiding students in the process of discussion group, so that some students are unable to work together in groups to complete the task.

d).The use of time at each learning stage is less effective in use by teachers.

Findings on these points are similar to the results of data processing on the questionnaire of teacher and student activity observed by the observer team. The results of the processed data showed that on the core activities of teachers only meet the criteria of "enough", while the preliminary and closing activities indicate the criteria of "good". The following is a presentation of the results of data processing on the questionnaire of teacher and student activity in cycle I.

Table 2. Teacher Activity and Students of Cycle I

\begin{tabular}{|c|c|c|c|c|c|c|c|}
\hline \multirow[b]{2}{*}{ No. } & \multirow[b]{2}{*}{ Stages } & \multicolumn{5}{|c|}{ Activities of Cycle I } & \multirow[b]{2}{*}{ Category } \\
\hline & & $\begin{array}{c}\text { Observer } \\
1\end{array}$ & $\begin{array}{c}\text { Observer } \\
2\end{array}$ & Averages & $\begin{array}{l}\text { Max } \\
\text { Score }\end{array}$ & $\%$ & \\
\hline 1 & Introduction activities & 4 & 4 & 4 & 5 & $80 \%$ & Good \\
\hline 2 & Core activities & 15 & 15 & 15 & 20 & $75 \%$ & Enough \\
\hline 3 & Closing activities & 4 & 4 & 4 & 5 & $80 \%$ & Good \\
\hline & Total & 23 & 23 & 23 & 30 & $78.3 \%$ & Enough \\
\hline
\end{tabular}

Some of the weaknesses found by the observer team and the results of the analysis of the questionnaire of teacher and student activities indicate that the researcher must make some improvements in teaching and learning process. This is done by researchers in the next cycle, which is cycle II. The researcher must maximize the effort to optimize the application of instructional media by using the media of static fluid aiming (Macromedia Flash) with start by giving motivation to the students, directing and guiding the students during discussion activity, building cooperative principle in group to finish the task.

\subsection{Cycle II}

The cycle II is implemented based on the results of reflection in cycle I, which indicates that the need for implementation of cycle II. Implementation of this cycle II is held on 19-20 April 2017 with floating material and the law of Archimedes. Implementation of cycle II is also done with two actions that are actions 3 and 4. Researchers activities in cycle II begins with the re-planning activities by preparing Teaching Implementation Plan, Media animation, Student's Worksheet, preparing observation sheet of teacher and student activity, sheets of student responses and prepare the test items of cycle II. Furthermore, the researcher conducted the initial activity by motivating the students and apperception by asking why the needle could sink while the ship in the ocean could float, the researcher tells the students the material to be taught is the law of Archimedes by applying the media of static fluid animation with Macromedia Flash.

The learning process is done by forming a learning group. The researcher guides and directs the students to be active in their respective groups ie to experiment according to the steps in the Student's Worksheet. Then the researcher asks the students to conclude the observed data from the experiments that have been done for subsequent of presented. For each group who are active and can present the results of the experiment in the award of praise.After the learning process by using macromedia flash animation media is done, to all students in giving the final test of cycle II to see student learning outcomes in cycle II. 
Based on the Figure 2 above can be seen that the number of students who have meet the the criteria of student's learning outcomes in the school is only 22 students or equal to $88 \%$ of the total number of students treated by using media animation with Macromedia Flash. This has shown a significant increase between the results of cycle I with the results of the test cycle II. And 3 students or by $12 \%$ of students still do not meet the criteria of student's learning outcomes. This indicates that the criteria mastery at least both individually and classically has achieved.The test results for 10 questions given to students are as follows:

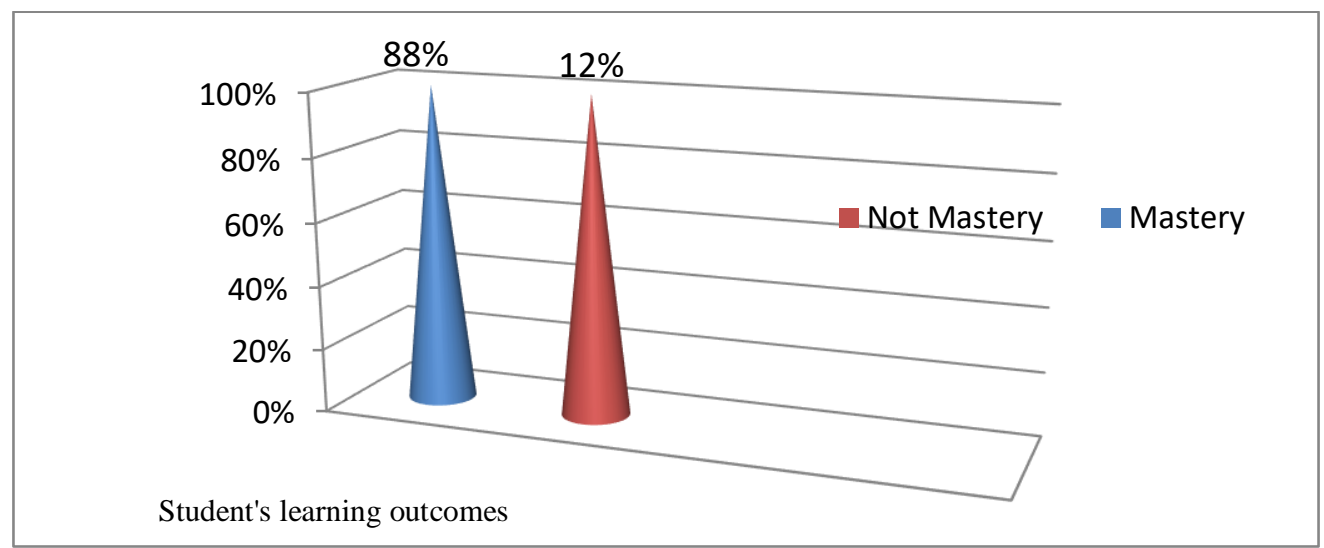

Figure 2. Results of Student Test of Cycle II

The attainment of minimum the criteria of student's learning outcomes is also seen from the results of the analysis on the questionnaire of teacher and student activity. The results of the analysis indicate that in teaching and learning process teachers and students have performed their respective functions well. Master has been very capable of bringing students to fully engage in the learning process from beginning to end. The result of activity analysis of teacher and student in cycle II is as follows:

Table 3. Teacher Activity and Students of Cycle II

\begin{tabular}{|c|c|c|c|c|c|c|c|}
\hline \multirow[b]{2}{*}{$\begin{array}{c}\text { No } \\
\text {. }\end{array}$} & \multirow[b]{2}{*}{ Stages } & \multicolumn{5}{|c|}{ Activities of Cycle I } & \multirow[b]{2}{*}{ Category } \\
\hline & & $\begin{array}{c}\text { Observer } \\
1\end{array}$ & $\begin{array}{c}\text { Observer } \\
2\end{array}$ & Averages & $\begin{array}{l}\text { Max } \\
\text { Score }\end{array}$ & $\%$ & \\
\hline 1 & $\begin{array}{l}\text { Introduction } \\
\text { activities }\end{array}$ & 5 & 5 & 5 & 5 & $100 \%$ & Good \\
\hline 2 & Core activities & 17 & 17 & 17 & 20 & $85 \%$ & Enough \\
\hline 3 & Closing activities & 5 & 5 & 5 & 5 & $100 \%$ & Good \\
\hline & Total & 27 & 27 & 27 & 30 & $95 \%$ & Very Good \\
\hline
\end{tabular}

The above table shows that after the teacher conducted teaching learning activitiesusing static fluid animated media (Macromedia Flash) and the result of data analysis on teacher and student activity questionnaires, the influence of teacher action during the learning activities took place. This can be seen from some successes of teachers and students, namely:

a). Teachers are able to apply the media of

Macromedia Flash animation for learning well

b). The motivation that the teacher has given is effective.

c). Students have been actively involved in the learning process. 
Based on the success that has been achieved, the researcher and the observer team decided not to continue learning in the next cycle. After the execution of cycle, I and II finished in carrying out, at the end of the meeting the researchers provide a questionnaire response to all students. This response questionnaire is intended to find out the students' responses to the learning process by using static fluid animation media with Macromedia Flash. The results of the analysis of the questionnaire response have been distributed is that there are $78.8 \%$ of students are very happy to study the physics of the concept of static fluid using static fluid animation media with Macromedia Flash, then $16.4 \%$ of students express happy. This percentage indicates that students respond very positively to the application of static fluid animation media with Macromedia Flash. Students feel enthusiastic to follow the process of physics learning.

The presence of static fluid animation with Macromedia Flash is also very helpful for students to understand the activities of physics practicum fluid static concept in accordance with the direction of Student's Worksheet and their teachers. Students appear to be more enthusiastic and more creative in practical activities. This is very plasticity in cycle II which is marked by the achievement of minimum completeness criteria of student learning outcomes. Thus it can be said that the process of teaching and learning by using Macromedia flash animation media can improve students learning results of class X IPA 1 on the concept of static fluid in Peusangan Islamic School.

Based on findings of the researchers can be said that these findings are in line with research ever conducted by Sumarni, et al [9] with the title "multimedia-based learning to Improve mastery of chemistry concepts and thinking skills of students". The study found that the application of MPK based on interactive multimedia can improve the mastery of chemical concept of integrated high-thinking thinking ability of chemistry teacher candidate up to high level of N-Gain category for critical thinking ability,creative, decision-making ability and problem solving". with research conducted by Wiyono, et al [12] who found that the use of interactive multimedia-based learning style is more effective than conventional learning in improving the mastery of the concept of physics solid introduction.

\section{Conclusions}

Based on the results of the discussion of research activities by using the media of static fluid animation with Macromedia Flash which is implemented in the class X IPA 1 Peusangan Islamic School can be concluded that:

1. There are increased student learning outcomes of class X Peusangan Islamic School on the concept of static fluid using static fluid animation media (Macromedia Flash), this is evident from the results in the first cycle (68\%), and the second cycle increased to (88\%). The results fall into very good categories.

2. The activity of teacher and students of class X Peusangan Islamic School on the concept of static fluid has shown very good category and experience improvement that cycles I am 78,33\% and cycle II increase to $95 \%$.

3. Response students class X Peusangan Islamic School against the use of media animation Macromedia Flash, in general, that is $78.8 \%$ expressed very happy and want to learn again with media animation of Macromedia flash. 


\section{Suggestion}

1. Researchers suggest for further research, should the creation of animation media for students of madrasah aliah especially for lesson IPA preferably animated media that is designed is a direct simulation of the lab that they will do in the classroom.

2. This research only observes and analyzes the students 'learning outcomes, for further research can be developed observation on high thinking ability of students such as critical thinking skill or students' creative thinking skill.

\section{References}

[1] Arikunto, Suharsimi,dkk. 2010. PenelitianTindakanKelas. Jakarta: BumiAksara.

[2] Brennan. Karen. 2014. Audience in the service of learning: how kids negotiate attention inan online community of interactive media designers. Journal InternationalLearning Media and Technology.

[3] Fonna, M., \& Mursalin, M. (2018). Role of Self-Efficacy Toward Students' Achievement in Mathematical Multiple Representation Ability (MMRA). Jurnal Ilmiah Peuradeun, 6(1), 31-40.

[4] Gee E, et al. 2017. Video gaming as digital media, play, and family routine: implications for understanding video gaming and learning in family contexts. Journal Learning Media and technology 42(4): 468-482

[5] Raiser, et al. 2017. Scaling Up Three-Dimensional Science Learning Through Teacher-Led Study Groups Across a State. Journal of Teacher Education 68(3): 280-298

[6] Sadiman, Arief S. 2007. Media Pendidikan, Pengertian,Pengembangan,danPemanfaatannya, Jakarta : PT Raja GrafindoPersada.

[7] Selwyn N, et al. 2016. High-tech, hard work: an investigation of teachers' work in the digital age. Journal Learning Media and technology 42(4): 390-405

[8] Sudijono. A. 2005. PengantarStatistikPendidikan. Jakarta: Rineka Cipta.

[9] Sumarni Woro, Sudarmin, Kadarwati Sri. 2013. Pembelajaran Berbasis Multimedia untuk Meningkatkan Penguasaan Konsep Kimia dan Keterampilan Berpikir Mahasiswa. JurnalIlmuPendidikanTerakreditasi No.1 jilid 19.Tahun2013. Malang: UniversitasNegeri Malang.

[10] Starmoen S, et al. 2015. High school physical education: What contributes to the experience of flow.European Physical Education Review 21(2): 139-154.

[11] Thibaut P, Curwood. J.S, Carvalho.L\& Simpson. A. 2014. Moving across physical and online spaces: a cas study in a blended primary classroom. Journal InternasionalLearning Media and Technology.

[12] Wiyono k, A Liliasari, Paulus C T.2012. Model Multimedia interaktif Berbasis Gaya Belajar Untuk Meningkatkan Penguasaan Konsep Pendahuluan Fisika Zat Padat. JPFI, 8(1), 78-82. 